\title{
Stuck at the Bottom Rung: Occupational Characteristics of Workers with Disabilities
}

\author{
H. Stephen Kaye
}

Published online: 7 April 2009

(c) The Author(s) 2009. This article is published with open access at Springerlink.com

\begin{abstract}
Introduction The proportion of workers reporting disabilities varies tremendously across occupations. Although differences in the occupational distributions may partly explain the large disparities in earnings and job security between workers with and without disabilities, little is known about the reasons that workers with disabilities are underrepresented in certain occupations and overrepresented in others. Methods Using a large, national survey of the US population combined with official data on the skill and experience requirements and occupational risks of 269 occupations, a multilevel regression analysis was performed to identify occupational and individual factors that influence the representation of workers with disabilities across occupations. Models of overall, sensory, mobility, and cognitive disability were constructed for working-age labor force participants, as were models of overall disability for younger, in-between, and older workers. Results At the occupational level, reported disability is negatively associated with occupational requirements for information and communication skills and with the amount of prior work experience that is required, after controlling for individual factors such as age and educational attainment. Little relationship is found between disability status and a set of occupational risk factors. These findings generally hold true across disability types and age groups. Conclusions Even after taking into account their lower average educational attainment, workers with disabilities appear to be disproportionately relegated to entry-level occupations that do not emphasize the better-
\end{abstract}

\section{H. S. Kaye $(\square)$}

Institute for Health \& Aging, University of California San

Francisco, 3333 California Street Suite 340, San Francisco,

CA 94118, USA

e-mail: steve.kaye@ucsf.edu remunerated job skills. Underemployment results in lower wages and less job security and stability. Possible reasons include employer discrimination, low expectations, deficits in relevant skills or experience, and work disincentives.

Keywords People with disabilities - Employment . Occupations $\cdot$ Job skills $\cdot$ Career mobility

\section{Introduction}

US adults with disabilities are employed at much lower levels, and on average earn substantially less when they do work, than their counterparts without disabilities [1, 2]. Workers with disabilities also have jobs that are much less stable, with twice the rate of job loss as other workers, far more periods of unemployment [3], double the rate of short-term or contractual employment $[4,5]$, and lower perceived job security [6]. These issues are interrelated, because the difficulty of finding steady work paying a decent wage undoubtedly deters people with disabilities from entering the labor force; job insecurity or low pay may also lead those acquiring disabilities to apply for cash benefits rather than seeking needed accommodations and remaining employed.

Differences in the occupations held by labor force participants with and without disabilities may be partly responsible for the poorer labor force experiences of the former group. Workers with disabilities are much less likely than their non-disabled counterparts to be employed in professional and managerial occupations (24.6 vs. $34.7 \%$ ), the highest-paid major occupational categories, and correspondingly more likely to have jobs in the two lowest-paid categories: service occupations (21.4 vs. $16.1 \%)$ and production, transportation, and material moving occupations 
(17.0 vs. $12.7 \%)$ [2, 7]. In more general terms, workers with disabilities are less likely to be supervisors, less likely to participate in decision making, and more likely to be closely supervised than those without disabilities [6]. As a consequence of these occupational differences, statistical models of earnings levels of workers with and without disabilities often use broad occupational classifications as explanatory variables to partly account for wage gaps (for a recent review, see [8]).

The question of why people with disabilities tend to hold lower-status and less-remunerated occupation has not been systematically explored. Three hypotheses came to mind as this research project was being formulated:

1. Workers with disabilities are overrepresented in lowerstatus occupations due to lower levels of so-called human capital, such as educational attainment and work experience.

2. Workers with disabilities are underrepresented in occupations requiring performance of physical or mental tasks they have difficulty performing in connection with their disabilities, and correspondingly overrepresented in other occupations not requiring such abilities.

3. Workers with disabilities are underrepresented in higher-status and higher-paid occupations due to discrimination or personal factors unrelated to qualifications or abilities.

This article explores the variation in the presence of workers with disabilities across occupations, using a multilevel statistical analysis of the demographic and disability characteristics of US labor force participants combined with the requirements and attributes of a wide range of occupations.

\section{Data Sources and Methods}

\section{Characteristics of Individual Labor Force Participants}

Demographic, disability, and occupational characteristics of 1.4 million US civilian labor force participants between the ages of 18 and 69 were obtained from the public use dataset of the 2006 American Community Survey (ACS), an annual, nationally representative survey conducted by the US Census Bureau [9]. The ACS provides a detailed classification of 469 civilian occupations, which were collapsed for this analysis into 269 categories with a minimum of approximately 1,000 respondents in each.

Also obtained from the ACS records were data on age, gender, race, Hispanic ethnicity, educational attainment, and disability status. Disability status is determined using a series of six questions covering sensory, mobility, and cognitive impairments, self-care limitations, difficulty leaving the home alone, and work disability; this analysis uses a summary classification for people endorsing any of the six items, plus separate models of the sensory, mobility, and cognitive disability items. For the present analysis, the ACS racial categories of "Asian" and "Native Hawaiian and other Pacific Islander" were combined to form a single Asian/Pacific Islander category; the other categories are African American, American Indian/Alaska Native, and white (treated as an omitted category in the models), with respondents checking more than one category classified in multiple groups. The educational attainment variable is collapsed into six categories: no high school, some high school but no diploma, high school diploma, some college but no bachelor's degree, college graduate (bachelor's), and advanced degree (master's or above).

\section{Characteristics of Occupations}

Occupational characteristics were obtained from the Occupational Information Network (O*NET) database, developed under the direction of the US Department of Labor, which contains detailed information on 812 occupations collected from panels of jobholders and occupational experts. For the present analysis, the occupational classification was collapsed by first combining categories, via simple averaging, to match the ACS classification and then further combining the resulting categories, using weighted averages based on labor force size estimates from the ACS, to match the 269 occupations used in the analysis.

Five occupational proficiency scales were derived from panel ratings of the level of performance required in 41 activities, obtained from the O*NET Generalized Work Activities domain. Ratings, averaged over the panelists, range from 0 , for activities deemed "not important" to the occupation, to 7 , for those requiring maximum proficiency. The scales were obtained as follows: Following a factor analysis, the five factors with greatest eigenvalues were retained and rotated (oblique Promax rotation) to increase interpretability. Items with loadings $>0.6$ on any factor were then assigned to the corresponding scale, and the scale score was obtained by taking an unweighted average of the ratings of the items assigned to it. The resulting scales are (1) using and evaluating information (Cronbach's $\alpha=0.96$ ), (2) supervising people (0.96), (3) communicating outside the organization (0.80), (4) handling objects and equipment (0.94), and (5) serving and caring for others (0.73 with only two items). Appendix Table 7 shows the factor loadings for the occupational activity items; numbers in bold indicate that the item was assigned to the indicated scale. 
A measure of required work experience prior to hiring is derived from the $\mathrm{O}^{*} \mathrm{NET}$ Experience and Training area, using the median of the panel's experience responses, collapsed into five levels: no experience required, up to 3 months, 4 months to 1 year, 13 months to 4 years, and $>4$ years of related prior work experience. Three dichotomous measures of occupational risk factors are derived from the $\mathrm{O}^{*} \mathrm{NET}$ Organizational Context area, all based on ratings by a majority of the panel: (1) workplace hazards are present if there is at least daily exposure to either hazardous conditions or hazardous equipment; (2) musculoskeletal strains are a risk for occupations involving kneeling, crouching, stooping, or crawling more than half the time, twisting or bending the body more than half the time, or making repetitive motions continuously or almost continuously; (3) high stress levels are an issue if the occupation involves daily conflict situations or daily interactions with angry or unpleasant people, or if the consequences of error are very or extremely serious or the work is highly or extremely competitive.

\section{Multilevel Modeling}

In order to simultaneously include both individual and occupational characteristics in the statistical models, the analysis uses a hierarchical modeling approach, with the individual as the lower-level unit of analysis (i.e., one record per labor force participant) and the occupation as the upper-level unit of analysis. Multilevel, random-intercept logistic regression models were estimated in version 6 of the HLM (Hierarchical Linear and Nonlinear Modeling) software package [10], using a penalized quasi-likelihood estimation procedure. The dependent variables in the models are dichotomous indicators of disability status: any type of disability, sensory impairment, mobility impairment and cognitive impairment. Survey sampling weights were used in all models. Results from HLM were compared with those obtained using the xtlogit procedure in Version 10 of the Stata statistical package [11], which uses adaptive quadrature to perform maximum likelihood estimation but does not use sampling weights, and the two methods were found to be consistent.

Because the aim is to explain the variation in disability rates across occupations, it seems appropriate to evaluate the quality of the models based on their ability to do so. A predicted disability rate for each occupation (with random effects in the model set to zero at both levels) can be obtained by using the model coefficients to predict the probability of disability for each survey respondent with a given occupation, and then computing the weighted average of those probabilities for the occupation. The predicted occupational disability rates can then be compared to the actual disability rates, and the variance of the occupation-level residuals can be compared to the variance of the actual disability rates. Thus, a measure of explained aggregate variance is obtained, and it is reported in the tables as a goodness-of-fit measure.

\section{Results}

As shown in Table 1, there is tremendous variation across occupations in the representation of workers with disabilities. The rate of overall disability varies more than tenfold across occupations, from $1.8 \%$ (among advertising, promotion, and public relations managers) to $19.7 \%$ (among dishwashers). For sensory disability, the range is from $0.5 \%$ (medical scientists) to $4.9 \%$ (dishwashers, again). Representation of people with mobility impairments varies from $0.9 \%$ (advertising, promotion, and public relations managers) to $9.6 \%$ (telephone and switchboard operators). For cognitive impairments, broadly defined, the range is from $0.06 \%$ (among dentists) to $12.4 \%$ (among dishwashers, yet again), a 200-fold variation.

The occupational proficiency scales, which have a minimum possible value of 0 and a maximum of 7 , also vary considerably. For using and evaluating information,

Table 1 Disability rate, occupational proficiency, work experience, and risk factor characteristics of occupations

\begin{tabular}{|c|c|c|c|c|}
\hline & Mean & SD & Min & Max \\
\hline \multicolumn{5}{|l|}{ Disability rate } \\
\hline Overall & 6.9 & 2.6 & 1.8 & 19.7 \\
\hline Sensory & 2.0 & 0.8 & 0.5 & 4.9 \\
\hline Mobility & 3.5 & 1.4 & 0.9 & 9.6 \\
\hline Cognitive & 1.9 & 1.3 & 0.1 & 12.4 \\
\hline \multicolumn{5}{|l|}{ Occupational proficiency scales } \\
\hline Using and evaluating information & 3.5 & 0.8 & 1.4 & 5.0 \\
\hline Supervising people & 2.7 & 0.9 & 0.9 & 5.0 \\
\hline Communicating outside organization & 3.0 & 1.0 & 0.8 & 5.5 \\
\hline Handling objects and equipment & 2.3 & 1.1 & 0.4 & 4.9 \\
\hline \multirow[t]{2}{*}{ Serving and caring for others } & 3.0 & 1.1 & 0.2 & 5.5 \\
\hline & \multicolumn{4}{|c|}{ Percent } \\
\hline \multicolumn{5}{|l|}{ Required work experience } \\
\hline None & 7.4 & & & \\
\hline$\leq 3$ months & 11.2 & & & \\
\hline 4-12 months & 23.0 & & & \\
\hline 13 months -4 years & 49.1 & & & \\
\hline$>4$ years & 9.3 & & & \\
\hline \multicolumn{5}{|l|}{ Occupational risks } \\
\hline Workplace hazards & 10.8 & & & \\
\hline Musculoskeletal strains & 20.8 & & & \\
\hline High stress levels & 39.0 & & & \\
\hline
\end{tabular}


scores range from 1.4 (for maids and housekeeping cleaners) to 5.0 (several occupations including physicians, physical scientists, and mathematicians). Scores for supervising people vary from a low of 0.9 (personal and home care aides) to a high of 5.0 (education administrators). For communicating outside the organization, the range is from 0.8 (for electronic equipment assemblers) to 5.5 (securities, commodities, and financial services sales agents). The range of scores for handling objects and equipment is 0.4 (for both human resource managers and aerospace engineers) to 4.9 (for both aircraft mechanics and electric power line installers). Finally, scores for serving and caring for people range from 0.2 (aerospace engineers) to 5.5 (physicians).

While a large majority of occupations require between 4 months and 4 years of related work experience, $7.4 \%$ have no experience requirements, such as taxi drivers, door-to-door sales agents, and reservation agents. The $9.3 \%$ of occupations requiring more than 4 years' experience include chief executives, financial managers, computer scientists, and carpenters. Among the occupational risks factors, occupations defined as inducing high stress levels are nearly four times as common as those exposing workers to hazardous conditions or equipment.

Demographic characteristics of working-age labor force participants are shown in Table 2. The mean age is just over 40 , nearly half are women, nearly one-third are

Table 2 Demographic characteristics of labor force participants (weighted to represent US civilian labor force)

\begin{tabular}{lcl}
\hline & Mean & SD \\
\hline Age & 40.4 & 12.7 \\
\hline & Percent & \\
\hline Female & 46.5 & \\
African American & 11.6 & \\
Asian/Pacific Islander & 5.2 & \\
American Indian/Alaska native & 1.3 & \\
Latino/Hispanic & 14.0 & \\
Educational attainment & & \\
No high school & 3.6 & \\
Some high school & 7.5 & \\
High school graduate & 29.2 & \\
Some college & 30.7 & \\
College graduate & 18.9 & \\
Advanced degree & 10.2 & \\
Disability rate & & \\
Overall & 7.1 & \\
Sensory & 2.0 & \\
Mobility & 3.7 & \\
Cognitive & 2.1 & \\
\hline
\end{tabular}

members of racial/ethnic minority groups, and a majority $(62.0 \%)$ have more than a high school education. Some $7.1 \%$ report any type of disability, with about half of those (3.7\%) reporting a mobility impairment.

The relationship between the occupational characteristics and the disability rate, median earnings, and the unemployment rate is illustrated in Table 3. For all of the scales except handling objects and equipment, occupations requiring the greatest proficiency have substantially less representation of workers with disabilities than those requiring minimal proficiency. Occupations requiring the highest proficiency in any skill set-with the exception, once again, of handling objects and equipment-have much higher earnings levels and much lower unemployment rates than those with minimal requirements. The using and evaluating information scale has the most dramatic differences, with the lowest quintile of occupations having twice the disability rate, $40 \%$ of the earnings, and four times the unemployment rate as the highest. In contrast to all the other scales, for handling objects and equipment, the disability rate and unemployment rate in the highest quintile are higher, and the median earnings level lower, than in the lowest quintile.

The amount of required work experience also has a large effect on all three measures. The disability rate is more than twice as high for entry-level occupations than for those requiring more than 4 years' experience. Not surprisingly, people in entry-level occupations earn much less than those in high-experience occupations ( $38 \%$ as much) and experience three times the level of unemployment. For two of the three measures of occupational risk, the disability rate and the unemployment rate are higher, and the earnings level is lower, when the risk is present. The opposite is true for occupations with high stress levels.

\section{Models of Overall Disability}

The analysis begins with a model of any type of disability, i.e., endorsement of one or more of the six disability measures in the ACS. Results from three models are shown in Table 4: an initial model including only occupationallevel factors, a second model to which individual factors except education have been added, and a final model with all factors included.

Among the occupational factors, two of the occupational proficiency scales are statistically significant in all three models: using and evaluating information and communicating outside the organization. Three of the four indicator variables for required work experience are significant across models, but the occupational risk factors are not significant in any of the models. The addition of the individual factors has only a modest effect on the odds ratios and significance levels for the occupational 
Table 3 Mean disability rate, median annual earnings, and mean unemployment rate, by occupational characteristics

\begin{tabular}{|c|c|c|c|c|c|c|}
\hline & \multicolumn{2}{|c|}{ Disability rate $(\%)$} & \multicolumn{2}{|c|}{ Median earnings $^{\mathrm{a}}(\$)$} & \multicolumn{2}{|c|}{ Unemployment rate $(\%)$} \\
\hline & Lowest quintile & Highest quintile & Lowest quintile & Highest quintile & Lowest quintile & Highest quintile \\
\hline \multicolumn{7}{|l|}{ Occupational proficiency scales } \\
\hline Using and evaluating information & 9.1 & 4.4 & 25,000 & 62,000 & 8.6 & 2.2 \\
\hline Supervising people & 8.9 & 4.9 & 27,000 & 53,000 & 7.7 & 2.6 \\
\hline Communicating outside org. & 9.5 & 5.0 & 28,000 & 51,000 & 7.5 & 2.8 \\
\hline Handling objects and equipment & 6.1 & 8.4 & 41,000 & 33,300 & 4.0 & 7.0 \\
\hline Serving and helping others & 7.3 & 5.6 & 38,000 & 45,000 & 5.6 & 2.7 \\
\hline Required work experience & None & $>4$ years & None & $>4$ years & None & $>4$ years \\
\hline Level required & 10.5 & 4.8 & 23,000 & 60,000 & 9.4 & 3.1 \\
\hline Occupational risks & No & Yes & No & Yes & No & Yes \\
\hline Workplace hazards & 6.9 & 8.8 & 38,000 & 32,000 & 5.2 & 7.4 \\
\hline Musculoskeletal strains & 6.7 & 9.3 & 40,000 & 29,000 & 5.0 & 7.4 \\
\hline High stress levels & 7.4 & 6.4 & 33,300 & 45,000 & 5.9 & 4.3 \\
\hline
\end{tabular}

${ }^{a}$ Median annual earnings in all jobs for full-time, year-round workers

factors, with the odds ratio for using and evaluating information increasing (closer to unity) once education is included.

The full multilevel model is explains $66.3 \%$ of the occupational-level variation in the disability rate, a substantially higher level than the occupation-only model (53.5\%). Occupational factors, worker educational attainment, and other demographic factors all appear to have major, independent influences on the representation of workers with disabilities across occupations.

In the full model, the odds ratio of 0.87 for using and evaluating information translates to predicted disability rates, controlling for education and other factors, ranging from $4.9 \%$ (for the occupation requiring the greatest proficiency) to $7.9 \%$ (least proficiency); for communicating outside the organization, the odds ratio of 0.93 yields a range of predicted disability rates from $5.1 \%$ (greatest proficiency) to $7.2 \%$ (least). Controlling for other factors, entry-level occupations would be expected to have a disability rate of $7.8 \%$, compared to $5.1 \%$ for those requiring the highest level of experience. Individual factors account for part, but by no means all, of the gaps in disability rates shown in Table 3.

Among individual factors, age has a significant, non-linear effect, and Asians and Pacific Islanders are predicted to have substantially less disability than nonHispanic whites, as are Latinos. In contrast, American Indians and Alaska Natives have more than twice the odds of having a disability as non-Hispanic whites. Four of the five education indicators are significant and $<1$, with the values decreasing markedly as the level of education increases.
Models of Sensory, Mobility, and Cognitive Disability

Three additional models test whether the same predictors apply across different types of disability. As Table 5 shows, the occupational proficiency scale on using and evaluating information is highly significant and has an odds ratio that is $<1$ in all models, with an especially pronounced effect in the model of cognitive disability. The scale on communicating outside the organization is significant and $<1$ in the sensory and physical disability models, with a larger effect in the sensory model. The other scales are not significant in any of the models.

The indicators of required work experience show the same patterns as in the overall disability models, with odds ratios steadily declining as experience requirements increase. The effect is particularly striking in the cognitive disability model, in which the odds of having a disability in occupations requiring the most experience are half those in entry-level jobs (predicted rates are 1.2 and 2.3\%). The occupational risk variables are not statistically significant, except for the high stress indicator, which reaches a modest level of statistical significance $(P=0.02,0.04)$ and has a value of $<1$ in the sensory and cognitive models.

Among the individual factors, the effects of gender and age vary considerably across models, but the effects of race are ethnicity is mostly consistent. The odds ratios for the Asian/Pacific Islander and Latino indicators are highly significant and much less than unity in all models, and that for American Indians and Alaska Natives is $>2$ for all disability types. The African American indicator, in contrast, has an odds ratio substantially $<1$ in the sensory and cognitive models but $>1$ in the mobility model. The 
Table 4 Odds ratios from the multilevel regression models of overall disability

\begin{tabular}{|c|c|c|c|}
\hline & $\begin{array}{l}\text { Occupational } \\
\text { factors only } \\
\text { Odds ratio }(95 \% \mathrm{CI})\end{array}$ & $\begin{array}{l}\text { Occupational factors } \\
\text { plus sex, age, race/ethnicity } \\
\text { Odds ratio }(95 \% \text { CI })\end{array}$ & $\begin{array}{l}\text { Full multilevel } \\
\text { model } \\
\text { Odds ratio }(95 \% \mathrm{CI})\end{array}$ \\
\hline \multicolumn{4}{|l|}{ Occupational factors } \\
\hline \multicolumn{4}{|l|}{ Occupational proficiency scales } \\
\hline Using and evaluating info. & $\begin{array}{l}0.803 * * \\
(0.755,0.855)\end{array}$ & $\begin{array}{l}0.773 * * \\
(0.728,0.821)\end{array}$ & $\begin{array}{l}0.871 * * \\
(0.827,0.916)\end{array}$ \\
\hline Supervising people & $\begin{array}{l}1.001 \\
(0.946,1.059)\end{array}$ & $\begin{array}{l}0.981 \\
(0.928,1.038)\end{array}$ & $\begin{array}{l}1.000 \\
(0.951,1.052)\end{array}$ \\
\hline Communicating outside org. & $\begin{array}{l}0.908 * * \\
(0.855,0.965)\end{array}$ & $\begin{array}{l}0.924 * \\
(0.870,0.981)\end{array}$ & $\begin{array}{l}0.925 * * \\
(0.878,0.974)\end{array}$ \\
\hline Handling objects and equip. & $\begin{array}{l}1.028 \\
(0.986,1.072)\end{array}$ & $\begin{array}{l}1.050 * \\
(1.006,1.095)\end{array}$ & $\begin{array}{l}0.989 \\
(0.952,1.028)\end{array}$ \\
\hline Serving and helping others & $\begin{array}{l}1.023 \\
(0.965,1.084)\end{array}$ & $\begin{array}{l}1.016 \\
(0.960,1.075)\end{array}$ & $\begin{array}{l}1.032 \\
(0.983,1.084)\end{array}$ \\
\hline \multicolumn{4}{|c|}{ Required work experience (omitted category = none) } \\
\hline$\leq 3$ months & $\begin{array}{l}0.937 \\
(0.797,1.102)\end{array}$ & $\begin{array}{l}0.952 \\
(0.806,1.123)\end{array}$ & $\begin{array}{l}0.903 \\
(0.774,1.053)\end{array}$ \\
\hline 4-12 months & $\begin{array}{l}0.808 * * \\
(0.699,0.935)\end{array}$ & $\begin{array}{l}0.808 * * \\
(0.694,0.940)\end{array}$ & $\begin{array}{l}0.790 * * \\
(0.689,0.907)\end{array}$ \\
\hline 13 months -4 years & $\begin{array}{l}0.759 * * \\
(0.655,0.879)\end{array}$ & $\begin{array}{l}0.736 * * \\
(0.633,0.857)\end{array}$ & $\begin{array}{l}0.730 * * \\
(0.634,0.840)\end{array}$ \\
\hline$>4$ years & $\begin{array}{l}0.648 * * \\
(0.533,0.787)\end{array}$ & $\begin{array}{l}0.627 * * \\
(0.515,0.762)\end{array}$ & $\begin{array}{l}0.633 * * \\
(0.530,0.756)\end{array}$ \\
\hline \multicolumn{4}{|l|}{ Occupational risks } \\
\hline Workplace hazards & $\begin{array}{l}1.033 \\
(0.928,1.149)\end{array}$ & $\begin{array}{l}1.009 \\
(0.902,1.128)\end{array}$ & $\begin{array}{l}1.016 \\
(0.916,1.128)\end{array}$ \\
\hline Musculoskeletal strains & $\begin{array}{l}1.019 \\
(0.919,1.129)\end{array}$ & $\begin{array}{l}1.045 \\
(0.939,1.164)\end{array}$ & $\begin{array}{l}1.015 \\
(0.927,1.111)\end{array}$ \\
\hline High stress levels & $\begin{array}{l}0.994 \\
(0.924,1.069)\end{array}$ & $\begin{array}{l}0.979 \\
(0.911,1.053)\end{array}$ & $\begin{array}{l}0.956 \\
(0.898,1.019)\end{array}$ \\
\hline \multicolumn{4}{|l|}{ Individual factors } \\
\hline Female & & $\begin{array}{l}1.009 \\
(0.982,1.037)\end{array}$ & $\begin{array}{l}0.979 \\
(0.953,1.006)\end{array}$ \\
\hline Age & & $\begin{array}{l}0.9995 \\
(0.9911,1.0080)\end{array}$ & $\begin{array}{l}1.0050 \\
(0.9965,1.0136)\end{array}$ \\
\hline $\mathrm{Age}^{2}$ & & $\begin{array}{l}1.0004^{* *} \\
(1.0003,1.0005)\end{array}$ & $\begin{array}{l}1.0003 * * \\
(1.0002,1.0004)\end{array}$ \\
\hline African American & & $\begin{array}{l}1.036 \\
(0.985,1.090)\end{array}$ & $\begin{array}{l}0.999 \\
(0.950,1.051)\end{array}$ \\
\hline Asian/Pacific Islander & & $\begin{array}{l}0.602 * * \\
(0.570,0.637)\end{array}$ & $\begin{array}{l}0.626 * * \\
(0.591,0.663)\end{array}$ \\
\hline American Indian/Alaska native & & $\begin{array}{l}2.190 * * \\
(2.061,2.326)\end{array}$ & $\begin{array}{l}2.124 * * \\
(2.000,2.256)\end{array}$ \\
\hline Latino & & $\begin{array}{l}0.740 * * \\
(0.688,0.797)\end{array}$ & $\begin{array}{l}0.660 * * \\
(0.610,0.714)\end{array}$ \\
\hline \multicolumn{4}{|c|}{ Educational attainment (omitted category $=$ no high school) } \\
\hline Some high school & & & $\begin{array}{l}1.049 \\
(0.974,1.129)\end{array}$ \\
\hline
\end{tabular}


Table 4 continued

\begin{tabular}{|c|c|c|c|}
\hline & $\begin{array}{l}\text { Occupational } \\
\text { factors only } \\
\text { Odds ratio }(95 \% \mathrm{CI})\end{array}$ & $\begin{array}{l}\text { Occupational factors } \\
\text { plus sex, age, race/ethnicity } \\
\text { Odds ratio }(95 \% \mathrm{CI})\end{array}$ & $\begin{array}{l}\text { Full multilevel } \\
\text { model } \\
\text { Odds ratio }(95 \% \mathrm{CI})\end{array}$ \\
\hline High school graduate & & & $\begin{array}{l}0.711 * * \\
(0.664,0.761)\end{array}$ \\
\hline Some college & & & $\begin{array}{l}0.704 * * \\
(0.657,0.755)\end{array}$ \\
\hline College graduate & & & $\begin{array}{l}0.437 * * \\
(0.404,0.472)\end{array}$ \\
\hline Advanced degree & & & $\begin{array}{l}0.384 * * \\
(0.351,0.419)\end{array}$ \\
\hline Explained aggregate variance (see Methods) & $53.5 \%$ & $59.6 \%$ & $66.3 \%$ \\
\hline
\end{tabular}

* $P<0.05 ;$ ** $P<0.01$

education variables show the same pattern of declining odds ratios with increasing attainment; the effect is especially pronounced in the cognitive model, with odds ratios for college graduate and advanced degree both $<0.25$.

\section{Age-Specific Models}

Older working-age adults often acquire aging-related disabilities after participating in the workforce for decades, a different experience from that of younger adults entering the workforce already having a disability. The final three models test whether the same set of occupational and individual predictors apply to younger (ages 18-29) and older (ages 55-69) working-age adults, as well as those in between (Table 6). Only the occupational proficiency factor on using and evaluating information is statistically significant in all three models, with odds ratios ranging from 0.83 to 0.92 . The communication factor has an odds ratio $<1$ in all models, but is significant only for the inbetween and older-worker models. Odds ratios for the work experience indicators decline with greater experience requirements, with the in-between model showing a larger effect than those for younger or older workers. The occupational risk factors are not significant in any model.

Once again, although the effects of age and gender are not consistent across models, those of Asian/Pacific Islander and American Indian/Alaska Native racial identify are similar. Odds ratios for the African American indicator varies from significant and $<1$ in the 18-29 model to insignificant in the 30-54 model to significant and $>1$ in the 55-69 model. The odds ratio for Latino ethnicity, while significant and $<1$ across models, increases from 0.50 for the youngest group to 0.84 for the oldest. As in the other models, odds ratios for the educational indicators generally decrease with increasing education for all age groups.

\section{Discussion}

An analysis of occupational and demographic data obtained by the US Census Bureau from 1.4 million labor force participants, combined with data on occupational characteristics from the $\mathrm{O}$ *NET database, reveals that workers with disabilities are substantially underrepresented in occupations that require proficiency in information, communication, and supervisory skills, the very qualities that afford higher earnings and better job security. Such workers are correspondingly overrepresented in entrylevel, unskilled, highly physical, and more hazardous occupations, all of which typically offer lower wages and greater risk of job loss or layoff. These descriptive findings confirm results from prior studies showing disability-related disparities in earnings [1, 2], unemployment levels [3], and occupational roles $[2,6,12,13]$, but add to the understanding of these differences by systematically exploring the characteristics of occupations in which people with disabilities are more or less likely to work.

Multilevel regression models, which simultaneously assess the effects of individual and occupational characteristics on the likelihood of a labor force participant having a disability, reveal that differences in educational attainment, age, and other individual characteristics can partly explain the differences in disability rates across occupations. But, in models of overall and specific types of disability and of workers in different age groups, the nature of the occupations themselves are also highly significant, adding considerably to their ability to explain the variation in disability rates. Consistently across all models, the amount of required work experience and the extent of required proficiency in information skills both negatively predict disability. And proficiency in communication skills is also significant and negative in most of the models. 
Table 5 Odds ratios from the multilevel regression models of sensory, mobility, and cognitive disability

\begin{tabular}{|c|c|c|c|}
\hline & $\begin{array}{l}\text { Sensory disability } \\
\text { Odds ratio }(95 \% \mathrm{CI})\end{array}$ & $\begin{array}{l}\text { Mobility disability } \\
\text { Odds ratio }(95 \% \mathrm{CI})\end{array}$ & $\begin{array}{l}\text { Cognitive disability } \\
\text { Odds ratio }(95 \% \mathrm{CI})\end{array}$ \\
\hline \multicolumn{4}{|l|}{ Occupational factors } \\
\hline \multicolumn{4}{|l|}{ Occupational proficiency scales } \\
\hline Using and evaluating info. & $\begin{array}{l}0.925 * * \\
(0.877,0.976)\end{array}$ & $\begin{array}{l}0.895 * * \\
(0.845,0.948)\end{array}$ & $\begin{array}{l}0.791 * * \\
(0.729,0.858)\end{array}$ \\
\hline Supervising people & $\begin{array}{l}1.019 \\
(0.970,1.072)\end{array}$ & $\begin{array}{l}0.969 \\
(0.914,1.027)\end{array}$ & $\begin{array}{l}1.013 \\
(0.929,1.103)\end{array}$ \\
\hline Communicating outside org. & $\begin{array}{l}0.898 * * \\
(0.851,0.947)\end{array}$ & $\begin{array}{l}0.9388 * \\
(0.883,0.997)\end{array}$ & $\begin{array}{l}0.935 \\
(0.867,1.009)\end{array}$ \\
\hline Handling objects and equip. & $\begin{array}{l}1.032 \\
(0.993,1.073)\end{array}$ & $\begin{array}{l}0.974 \\
(0.933,1.016)\end{array}$ & $\begin{array}{l}0.986 \\
(0.933,1.043)\end{array}$ \\
\hline Serving and helping others & $\begin{array}{l}1.026 \\
(0.974,1.082)\end{array}$ & $\begin{array}{l}1.050 \\
(0.989,1.113)\end{array}$ & $\begin{array}{l}1.013 \\
(0.946,1.085)\end{array}$ \\
\hline \multicolumn{4}{|c|}{ Required work experience (omitted category = none) } \\
\hline$\leq 3$ months & $\begin{array}{l}0.921 \\
(0.805,1.055)\end{array}$ & $\begin{array}{l}0.908 \\
(0.781,1.056)\end{array}$ & $\begin{array}{l}0.903 \\
(0.714,1.142)\end{array}$ \\
\hline 4-12 months & $\begin{array}{l}0.822 * * \\
(0.721,0.937)\end{array}$ & $\begin{array}{l}0.837 * * \\
(0.738,0.948)\end{array}$ & $\begin{array}{l}0.736^{*} \\
(0.583,0.929)\end{array}$ \\
\hline 13 months -4 years & $\begin{array}{l}0.804 * * \\
(0.703,0.919)\end{array}$ & $\begin{array}{l}0.786 * * \\
(0.690,0.895)\end{array}$ & $\begin{array}{l}0.638 * * \\
(0.504,0.807)\end{array}$ \\
\hline$>4$ years & $\begin{array}{l}0.726 * * \\
(0.614,0.858)\end{array}$ & $\begin{array}{l}0.683 * * \\
(0.572,0.816)\end{array}$ & $\begin{array}{l}0.504 * * \\
(0.372,0.683)\end{array}$ \\
\hline \multicolumn{4}{|l|}{ Occupational risks } \\
\hline Workplace hazards & $\begin{array}{l}1.042 \\
(0.951,1.141)\end{array}$ & $\begin{array}{l}1.018 \\
(0.919,1.128)\end{array}$ & $\begin{array}{l}1.008 \\
(0.859,1.184)\end{array}$ \\
\hline Musculoskeletal strains & $\begin{array}{l}1.071 \\
(0.984,1.165)\end{array}$ & $\begin{array}{l}0.977 \\
(0.882,1.082)\end{array}$ & $\begin{array}{l}0.949 \\
(0.833,1.081)\end{array}$ \\
\hline High stress levels & $\begin{array}{l}0.925 * * \\
(0.869,0.985)\end{array}$ & $\begin{array}{l}1.013 \\
(0.941,1.091)\end{array}$ & $\begin{array}{l}0.901 * \\
(0.817,0.994)\end{array}$ \\
\hline \multicolumn{4}{|l|}{ Individual factors } \\
\hline Female & $\begin{array}{l}0.673 * * \\
(0.647,0.700)\end{array}$ & $\begin{array}{l}1.164 * * \\
(1.124,1.206)\end{array}$ & $\begin{array}{l}1.015 \\
(0.963,1.071)\end{array}$ \\
\hline Age & $\begin{array}{l}1.008 * \\
(1.001,1.015)\end{array}$ & $\begin{array}{l}1.073 * * \\
(1.063,1.083)\end{array}$ & $\begin{array}{l}0.990 \\
(0.976,1.004)\end{array}$ \\
\hline $\mathrm{Age}^{2}$ & $\begin{array}{l}1.0004 * * \\
(1.0003,1.0004)\end{array}$ & $\begin{array}{l}0.9998 * * \\
(0.9997,0.9999)\end{array}$ & $\begin{array}{l}1.0001 \\
(1.0000,1.0003)\end{array}$ \\
\hline African American & $\begin{array}{l}0.821 * * \\
(0.771,0.874)\end{array}$ & $\begin{array}{l}1.171 * * \\
(1.107,1.239)\end{array}$ & $\begin{array}{l}0.813 * * \\
(0.761,0.869)\end{array}$ \\
\hline Asian/Pacific Islander & $\begin{array}{l}0.552 * * \\
(0.500,0.608)\end{array}$ & $\begin{array}{l}0.591 * * \\
(0.550,0.636)\end{array}$ & $\begin{array}{l}0.501 * * \\
(0.444,0.564)\end{array}$ \\
\hline American Indian/Alaska native & $\begin{array}{l}2.219 * * \\
(2.013,2.446)\end{array}$ & $\begin{array}{l}2.254 * * \\
(2.106,2.412)\end{array}$ & $\begin{array}{l}2.054 * * \\
(1.853,2.276)\end{array}$ \\
\hline Latino & $\begin{array}{l}0.749 * * \\
(0.695,0.807)\end{array}$ & $\begin{array}{l}0.769 * * \\
(0.719,0.824)\end{array}$ & $\begin{array}{l}0.422 * * \\
(0.363,0.490)\end{array}$ \\
\hline \multicolumn{4}{|c|}{ Educational attainment (omitted category $=$ no high school) } \\
\hline Some high school & $\begin{array}{l}0.980 \\
(0.888,1.081)\end{array}$ & $\begin{array}{l}1.086^{*} \\
(1.002,1.177)\end{array}$ & $\begin{array}{l}0.793 * * \\
(0.700,0.898)\end{array}$ \\
\hline High school graduate & $\begin{array}{l}0.776 * * \\
(0.706,0.852)\end{array}$ & $\begin{array}{l}0.759 * * \\
(0.705,0.818)\end{array}$ & $\begin{array}{l}0.453 * * \\
(0.400,0.512)\end{array}$ \\
\hline
\end{tabular}


Table 5 continued

\begin{tabular}{llll}
\hline & $\begin{array}{l}\text { Sensory disability } \\
\text { Odds ratio (95\% CI) }\end{array}$ & $\begin{array}{l}\text { Mobility disability } \\
\text { Odds ratio (95\% CI) }\end{array}$ & $\begin{array}{l}\text { Cognitive disability } \\
\text { Odds ratio (95\% CI) }\end{array}$ \\
\hline Some college & $0.764 * *$ & $0.789 * *$ & $0.403 * *$ \\
& $(0.696,0.839)$ & $(0.734,0.847)$ & $(0.348,0.465)$ \\
College graduate & $0.508 * *$ & $0.452^{* *}$ & $0.244 * *$ \\
Advanced degree & $(0.459,0.563)$ & $(0.413,0.494)$ & $(0.210,0.283)$ \\
& $0.439 * *$ & $0.397 * * 23 *$ & $0.223 *$ \\
Explained aggregate variance (see Methods) & $(0.391,0.491)$ & $(0.360,0.438)$ & $(0.190,0.261)$ \\
\hline
\end{tabular}

$* P<0.05 ; * * P<0.01$

The effects of these skill requirements on the representation of workers with disabilities, and the consequences in terms of earnings and job stability, are new to the literature; the strong effect of occupational experience requirements is consistent with a prior finding that workers with disabilities are promoted less often than their non-disabled peers [3]. The preponderance of workers with disabilities in unskilled, low-skilled, and entry-level occupations is somewhat at odds with studies showing that people in higher-skilled jobs who acquire disabilities are more likely to remain employed rather than leaving the labor force $[14,15]$.

The most unexpected findings are those relating to the specific skills that predict the representation of workers with disabilities in an occupation. One would suppose that people with disabilities, like other workers, would gravitate toward occupations that highlight their abilities, avoiding jobs emphasizing activities they would find difficult or impossible to perform. And certainly, employers ought to be hiring workers whose abilities match the demands of the job. One might naively believe, for example, that a sedentary occupation involving information or communication skills would be better suited to a person with mobility impairment than a physically demanding occupation, or that employers would be more likely to hire such a person for a sedentary than a physical job.

Another naive expectation might be that people with certain sensory impairments, especially blindness and low vision, would also be attracted by or selected into occupations emphasizing information or communication skills, for which assistive technologies are readily available to those needing them, rather than physical skills. On the other hand, one might suppose that people with cognitive disabilities, perhaps lacking advanced information skills, would choose or be relegated to occupations that emphasize physical abilities.

For all these suppositions, however, the reality is quite different. The models suggest that, controlling for other factors, people with disabilities are greatly underrepresented in occupations requiring proficiency in handling and evaluating information and in communicating with customers or others outside the organization. In contrast, people with physical disabilities (or any other type of disability) are not significantly underrepresented in occupations requiring physical skills in handling objects and equipment, nor are people with cognitive (or any other) disabilities overrepresented. The statistical models also find no association between the presence of workers with disabilities and the need for supervisory skills, a surprise given the clear differences in supervisory duties found in a prior study [6]. Skills in serving and caring for others were also not significant.

Aside from proficiency requirements across occupations, the amount of prior, related work experience needed to obtain a job in a given occupation plays a major role in influencing the presence of workers with disabilities, with far greater representation in entry-level than higher-status occupations. The effect is especially pronounced in the cognitive disability model. Although labor force participants with disabilities have, on average, less educational attainment than those without disabilities, this finding cannot be attributed to such differences, which have been controlled for in the models.

The general lack of statistical significance of the occupational risk factors in the models is another unexpected finding. These variables were included to test the hypothesis that workplace injuries or stress levels might result in greater work-related disability and therefore be a factor in the greater prevalence of workers with disabilities in certain occupations. But these results suggest the contrary; in fact, high stress levels are associated with a lower presence of sensory or cognitive disability. This finding is consistent with prior research suggesting that the level of job strain is associated with later risk of acquiring a disability [16]. The limited extent of risk factors tested is a weakness in the analysis; additional information on occupational risks, such as that obtained using data on rates of workplace injury, could be added in a future study. 
Table 6 Odds ratios from the multilevel regression models of overall disability by age group

\begin{tabular}{|c|c|c|c|}
\hline & $\begin{array}{l}\text { Ages } 18-29 \\
\text { Odds ratio }(95 \% \mathrm{CI})\end{array}$ & $\begin{array}{l}\text { Ages } 30-54 \\
\text { Odds ratio }(95 \% \mathrm{CI})\end{array}$ & $\begin{array}{l}\text { Ages } 55-64 \\
\text { Odds ratio }(95 \% \mathrm{CI})\end{array}$ \\
\hline \multicolumn{4}{|l|}{ Occupational factors } \\
\hline \multicolumn{4}{|l|}{ Occupational proficiency scales } \\
\hline Using and evaluating info. & $\begin{array}{l}0.831 * * \\
(0.766,0.903)\end{array}$ & $\begin{array}{l}0.869 * * \\
(0.821,0.919)\end{array}$ & $\begin{array}{l}0.918 * * \\
(0.868,0.970)\end{array}$ \\
\hline Supervising people & $\begin{array}{l}1.042 \\
(0.963,1.128)\end{array}$ & $\begin{array}{l}0.996 \\
(0.943,1.052)\end{array}$ & $\begin{array}{l}0.974 \\
(0.925,1.026)\end{array}$ \\
\hline Communicating outside org. & $\begin{array}{l}0.954 \\
(0.887,1.026)\end{array}$ & $\begin{array}{l}0.911 * * \\
(0.859,0.965)\end{array}$ & $\begin{array}{l}0.939 * \\
(0.889,0.992)\end{array}$ \\
\hline Handling objects and equip. & $\begin{array}{l}1.003 \\
(0.950,1.058)\end{array}$ & $\begin{array}{l}0.978 \\
(0.937,1.021)\end{array}$ & $\begin{array}{l}1.001 \\
(0.964,1.040)\end{array}$ \\
\hline Serving and helping others & $\begin{array}{l}0.986 \\
(0.917,1.061)\end{array}$ & $\begin{array}{l}1.042 \\
(0.985,1.102)\end{array}$ & $\begin{array}{l}1.044 \\
(0.993,1.097)\end{array}$ \\
\hline \multicolumn{4}{|c|}{ Required work experience (omitted category $=$ none) } \\
\hline$\leq 3$ months & $\begin{array}{l}0.943 \\
(0.790,1.125)\end{array}$ & $\begin{array}{l}0.870 \\
(0.734,1.032)\end{array}$ & $\begin{array}{l}0.936 \\
(0.807,1.086)\end{array}$ \\
\hline $4-12$ months & $\begin{array}{l}0.799 * * \\
(0.676,0.944)\end{array}$ & $\begin{array}{l}0.734 * * \\
(0.628,0.858)\end{array}$ & $\begin{array}{l}0.897 \\
(0.786,1.024)\end{array}$ \\
\hline 13 months -4 years & $\begin{array}{l}0.719 * * \\
(0.606,0.854)\end{array}$ & $\begin{array}{l}0.687 * * \\
(0.584,0.807)\end{array}$ & $\begin{array}{l}0.821 * * \\
(0.714,0.945)\end{array}$ \\
\hline$>4$ years & $\begin{array}{l}0.704 * * \\
(0.549,0.904)\end{array}$ & $\begin{array}{l}0.564 * * \\
(0.457,0.696)\end{array}$ & $\begin{array}{l}0.770 * * \\
(0.647,0.916)\end{array}$ \\
\hline \multicolumn{4}{|l|}{ Occupational risks } \\
\hline Workplace hazards & $\begin{array}{l}0.895 \\
(0.762,1.051)\end{array}$ & $\begin{array}{l}1.040 \\
(0.929,1.165)\end{array}$ & $\begin{array}{l}1.062 \\
(0.972,1.160)\end{array}$ \\
\hline Musculoskeletal strains & $\begin{array}{l}1.053 \\
(0.932,1.189)\end{array}$ & $\begin{array}{l}1.011 \\
(0.919,1.112)\end{array}$ & $\begin{array}{l}1.001 \\
(0.911,1.101)\end{array}$ \\
\hline High stress levels & $\begin{array}{l}0.941 \\
(0.857,1.033)\end{array}$ & $\begin{array}{l}0.966 \\
(0.901,1.036)\end{array}$ & $\begin{array}{l}0.973 \\
(0.911,1.039)\end{array}$ \\
\hline \multicolumn{4}{|l|}{ Individual factors } \\
\hline Female & $\begin{array}{l}0.937 * \\
(0.879,1.000)\end{array}$ & $\begin{array}{l}1.027 \\
(0.991,1.063)\end{array}$ & $\begin{array}{l}0.954 * \\
(0.915,0.995)\end{array}$ \\
\hline Age & $\begin{array}{l}1.238 * * \\
(1.109,1.381)\end{array}$ & $\begin{array}{l}0.999 \\
(0.979,1.019)\end{array}$ & $\begin{array}{l}1.038 \\
(0.930,1.159)\end{array}$ \\
\hline $\mathrm{Age}^{2}$ & $\begin{array}{l}0.9962 * * \\
(0.9940,0.9986)\end{array}$ & $\begin{array}{l}1.0004 * * \\
(1.0002,1.007)\end{array}$ & $\begin{array}{l}1.0000 \\
(0.9991,1.0009)\end{array}$ \\
\hline African American & $\begin{array}{l}0.771 * * \\
(0.713,0.834)\end{array}$ & $\begin{array}{l}1.023 \\
(0.967,1.082)\end{array}$ & $\begin{array}{l}1.171 * * \\
(1.097,1.250)\end{array}$ \\
\hline Asian/Pacific Islander & $\begin{array}{l}0.612 * * \\
(0.531,0.704)\end{array}$ & $\begin{array}{l}0.608 * * \\
(0.565,0.655)\end{array}$ & $\begin{array}{l}0.720 * * \\
(0.660,0.785)\end{array}$ \\
\hline American Indian/Alaska native & $\begin{array}{l}1.852 * * \\
(1.628,2.107)\end{array}$ & $\begin{array}{l}2.185 * * \\
(2.013,2.371)\end{array}$ & $\begin{array}{l}2.151 * * \\
(1.950,2.373)\end{array}$ \\
\hline Latino & $\begin{array}{l}0.500 * * \\
(0.444,0.563)\end{array}$ & $\begin{array}{l}0.676 * * \\
(0.620,0.737)\end{array}$ & $\begin{array}{l}0.843 * * \\
(0.781,0.911)\end{array}$ \\
\hline \multicolumn{4}{|c|}{ Educational attainment (omitted category $=$ no high school) } \\
\hline Some high school & $\begin{array}{l}1.428 * * \\
(1.224,1.666)\end{array}$ & $\begin{array}{l}1.078 \\
(0.996,1.167)\end{array}$ & $\begin{array}{l}0.817 * * \\
(0.743,0.899)\end{array}$ \\
\hline High school graduate & $\begin{array}{l}0.940 \\
(0.800,1.105)\end{array}$ & $\begin{array}{l}0.721 * * \\
(0.664,0.782)\end{array}$ & $\begin{array}{l}0.611 * * \\
(0.561,0.666)\end{array}$ \\
\hline
\end{tabular}


Table 6 continued

\begin{tabular}{|c|c|c|c|}
\hline & $\begin{array}{l}\text { Ages } 18-29 \\
\text { Odds ratio }(95 \% \mathrm{CI})\end{array}$ & $\begin{array}{l}\text { Ages } 30-54 \\
\text { Odds ratio }(95 \% \mathrm{CI})\end{array}$ & $\begin{array}{l}\text { Ages } 55-64 \\
\text { Odds ratio }(95 \% \mathrm{CI})\end{array}$ \\
\hline \multirow[t]{2}{*}{ Some college } & $0.753 * *$ & $0.737 * *$ & $0.644 * *$ \\
\hline & $(0.642,0.883)$ & $(0.678,0.802)$ & $(0.594,0.699)$ \\
\hline \multirow[t]{2}{*}{ College graduate } & $0.393 * *$ & $0.460 * *$ & $0.417 * *$ \\
\hline & $(0.326,0.474)$ & $(0.418,0.506)$ & $(0.378,0.460)$ \\
\hline \multirow[t]{2}{*}{ Advanced degree } & $0.351 * *$ & $0.383 * *$ & $0.365^{* *}$ \\
\hline & $(0.275,0.448)$ & $(0.345,0.425)$ & $(0.328,0.405)$ \\
\hline Explained aggregate variance (see Methods) & $57.0 \%$ & $66.5 \%$ & $63.3 \%$ \\
\hline
\end{tabular}

$* P<0.05 ; * * P<0.01$

The preponderance of workers with disabilities in entrylevel positions, and in occupations requiring little in the way of information or communication skills, has clear implications. As shown in Table 3, occupations with low levels in either skill or in required work experience have especially low earnings and high rates of unemployment. An analysis of the extent to which these occupational factors account for the lower earnings of workers with disabilities compared to their non-disabled counterparts is beyond the scope of this paper, but would make for an interesting future research project.

Workers with disabilities do not appear to be employed to their fullest potential, earning less and having less job security partly because they are employed in lower-paid occupations that do not take advantage of skills that are in the highest demand. There are several possible explanations. Clearly, one possibility is discrimination [8]. Workers with disabilities might be stuck in entry-level jobs because they are not getting equitable opportunities for promotion [3], not receiving the workplace accommodations necessary to perform more highly skilled work, or not being hired into better-paying jobs for which there is more competition. Employers might be relying on stereotypes about people with disabilities, relegating them to less prestigious, less visible jobs that do not require advanced information or communication skills. Or employers may deny them opportunities for training that would help them obtain those skills and enable them to advance their careers.

Another possibility is that there are real deficits in levels of relevant work experience between workers with and without disabilities. Labor force participants with disabilities may have work histories that are less solid than their non-disabled counterparts [13], because of temporary absences from the workforce or periods of part-time work; or, when an acquired disability necessitates a change in occupation, prior work experience might not be related to the current job. Although educational level is controlled for in the models, there may be differences in the specific skills that have been obtained through education or through prior jobs. The absence of data on work history and skill levels is a principal limitation of this study; national datasets other than the ACS have limited work history information but a much smaller sample size and a much less detailed occupational classification.

A third possible explanation for the disproportionate presence of workers with disabilities in certain lower-paid occupations rests in the workers themselves. Perhaps they do not actively pursue better-paying, more intellectually demanding jobs because their expectations for employment are low, believing either that they are not qualified for better jobs or that no employer will hire them despite their qualifications. Young adults with learning disabilities, for example, were found in one study to aspire to lower-prestige occupations than their peers without disabilities [17].

Alternatively, workers with disabilities may actually prefer jobs entailing fewer work hours and responsibilities and offering greater flexibility and less psychological stress that might worsen their health or functioning $[5,18]$. Or they may stick with lower-paying jobs to retain public healthcare coverage or cash benefits, which would be lost if their income increased beyond the eligibility limit [19]. Whether due to lack of ambition or rational choice, many workers with disabilities might be voluntarily underemployed, settling for lower-status, lower-paid jobs rather than pursuing opportunities for advancement or training.

Workers with disabilities cannot achieve parity with their non-disabled counterparts in terms of earnings, benefits, and job security until they have equal access to and equal representation in better-paid and more highly skilled occupations. Vocational rehabilitation agencies, special education programs, and other service providers must reconsider any practice of encouraging people with disabilities to settle for jobs that do not take full advantage of their skills, abilities, and experience. Incentives to place people in any job, rather than a good job matching the person's interests and abilities, may be counterproductive. Lack of ambition in a job search, or in pursuing opportunities for advancement, may lead to a lifetime of underemployment, low pay, and job insecurity. 
Furthermore, inflexible income limits to eligibility for government benefit programs should be changed, lest they continue to serve as a disincentive to advancement into higher paying jobs.

It is likely that discrimination plays a role in the apparent exclusion of large numbers of workers with disabilities from better-paid and more stable occupations. The dearth of representation in occupations involving contact with the public - in other words, as visible representatives of the business or organization-is particularly telling. Employers must be better educated in recognizing the talents and abilities of workers with disabilities, and of their potential, given appropriate accommodations, to perform a wide variety of job tasks [20]. They should also include disability status as a component in their efforts to increase and showcase workplace diversity, reversing what is apparently the current practice of keeping their employees with disabilities shielded from public exposure.

Finally, national disability employment policy must further expand its focus beyond getting people with disabilities into the workforce, to also include fostering quality careers that pay well and offer stability and opportunities for advancement. Such services ought to be provided not only to people entering or attempting to reenter the labor force, but also to employed people with disabilities working in entry-level, low-skill jobs. Workers with disabilities need greater opportunity to advance into higher quality occupations, increase their earnings potential, and improve their job security and social status. The promise of a brighter employment future would go a long way toward encouraging greater labor force participation among people with disabilities, substantially increasing both employment and income levels and reducing reliance on benefit programs.

By focusing on factors associated with occupational differences, and finding large discrepancies between the backgrounds and abilities of workers with disabilities and the types of jobs they hold, this study adds to the understanding of employment disparities between people with and without disabilities. A person's occupation affects not only his or her earnings potential, but also the level of job security and stability, job satisfaction, motivation to join and remain attached to the labor force, and alignment between job tasks and the person's abilities, perhaps in the face of future declines in functional abilities or health status. Future research should focus on the barriers to better and more appropriate careers for workers with disabilities, and pinpoint strategies for overcoming those barriers.

Acknowledgments This research was supported by a grant from the National Institute on Disability and Rehabilitation Research, US Department of Education, to the Burton Blatt Institute at Syracuse University, as part of the Demand-Side Employment Placement Models project; Grant No. H133A060033. The author thanks Doug Kruse, Peter Blanck, and Naomi Uziel Schreuer for incisive comments.

Open Access This article is distributed under the terms of the Creative Commons Attribution Noncommercial License which permits any noncommercial use, distribution, and reproduction in any medium, provided the original author(s) and source are credited.

\section{Appendix}

See Table 7.

Table 7 Occupational activity items, proficiency scales, and rotated factor loadings

\begin{tabular}{|c|c|c|c|c|c|}
\hline \multirow[t]{2}{*}{ Occupational activity item } & \multicolumn{5}{|c|}{ Occupational proficiency scales } \\
\hline & 1 & 2 & 3 & 4 & 5 \\
\hline Getting Information & 0.88 & -0.05 & 0.05 & -0.19 & 0.11 \\
\hline Monitoring processes, materials, or surroundings & 0.77 & 0.07 & -0.25 & 0.37 & 0.26 \\
\hline Identifying objects, actions, and events & 0.92 & -0.11 & -0.12 & 0.09 & 0.31 \\
\hline Inspecting equipment, structures, or material & 0.22 & 0.06 & -0.19 & 0.80 & 0.04 \\
\hline Estimating quantifiable characteristics & 0.53 & 0.31 & -0.19 & 0.33 & -0.21 \\
\hline Judging the qualities of things, services, or people & 0.44 & 0.39 & 0.10 & 0.12 & 0.14 \\
\hline Processing information & 0.97 & -0.07 & -0.07 & -0.16 & -0.11 \\
\hline Evaluating info. to determine compliance $\mathrm{w} /$ standards & 0.82 & 0.13 & -0.22 & 0.02 & 0.03 \\
\hline Analyzing data or information & 0.91 & 0.04 & -0.01 & -0.04 & -0.14 \\
\hline Making decisions and solving problems & 0.74 & 0.18 & 0.11 & 0.11 & 0.04 \\
\hline Thinking creatively & 0.37 & 0.32 & 0.29 & 0.11 & -0.15 \\
\hline Updating and using relevant knowledge & 0.97 & -0.20 & 0.18 & 0.15 & 0.05 \\
\hline Developing objectives and strategies & 0.35 & 0.51 & 0.18 & -0.02 & -0.02 \\
\hline
\end{tabular}


Table 7 continued

\begin{tabular}{|c|c|c|c|c|c|}
\hline \multirow[t]{2}{*}{ Occupational activity item } & \multicolumn{5}{|c|}{ Occupational proficiency scales } \\
\hline & 1 & 2 & 3 & 4 & 5 \\
\hline Scheduling work and activities & 0.19 & 0.70 & 0.12 & 0.04 & -0.09 \\
\hline Organizing, planning, and prioritizing work & 0.49 & 0.35 & 0.13 & -0.11 & -0.10 \\
\hline Performing general physical activities & -0.32 & 0.07 & 0.11 & 0.88 & 0.30 \\
\hline Handling and moving objects & -0.34 & -0.05 & 0.03 & 0.82 & 0.19 \\
\hline Controlling machines and processes & -0.04 & -0.03 & -0.14 & 0.83 & -0.07 \\
\hline Operating vehicles, mechanized devices, or equipment & -0.10 & -0.02 & 0.17 & 0.85 & 0.08 \\
\hline Interacting with computers & 0.78 & -0.16 & 0.13 & -0.23 & -0.25 \\
\hline Drafting, laying out, specifying tech. equipment & 0.16 & 0.19 & -0.01 & 0.59 & -0.46 \\
\hline Repairing and maintaining mechanical equipment & -0.09 & -0.05 & 0.12 & 0.95 & -0.12 \\
\hline Repairing and maintaining electronic equipment & 0.30 & -0.24 & 0.16 & 0.83 & -0.16 \\
\hline Documenting/recording information & 1.06 & -0.24 & -0.06 & -0.05 & 0.16 \\
\hline Interpreting the meaning of information for others & 0.86 & -0.02 & 0.05 & -0.11 & -0.03 \\
\hline Communicating w/ supervisors/peers/subordinates & 0.61 & 0.30 & 0.04 & -0.11 & -0.05 \\
\hline Communicating with persons outside organization & 0.40 & -0.02 & 0.70 & -0.03 & 0.18 \\
\hline Establishing \& maintaining interpersonal relationships & 0.36 & 0.16 & 0.39 & -0.24 & 0.27 \\
\hline Assisting and caring for others & 0.15 & 0.12 & 0.10 & 0.05 & $\mathbf{0 . 8 0}$ \\
\hline Selling or influencing others & -0.08 & 0.21 & 0.77 & 0.06 & 0.14 \\
\hline Resolving conflicts and negotiating with others & 0.10 & 0.56 & 0.30 & -0.14 & 0.26 \\
\hline Performing for or working directly with the public & -0.09 & -0.08 & 0.77 & 0.14 & 0.77 \\
\hline Coordinating the work and activities of others & -0.06 & 0.97 & -0.06 & 0.02 & -0.04 \\
\hline Developing and building teams & 0.04 & 0.91 & -0.11 & -0.09 & 0.04 \\
\hline Training and teaching others & 0.24 & 0.68 & -0.16 & 0.07 & 0.20 \\
\hline Guiding, directing, and motivating subordinates & -0.21 & 1.14 & -0.10 & 0.00 & 0.00 \\
\hline Coaching and developing others & -0.07 & 0.93 & -0.03 & -0.03 & 0.15 \\
\hline Provide consultation and advice to others & 0.37 & 0.55 & 0.08 & -0.05 & -0.08 \\
\hline Performing administrative activities & 0.38 & 0.30 & 0.24 & -0.24 & 0.07 \\
\hline Staffing organizational units & -0.24 & 1.04 & 0.00 & -0.09 & -0.03 \\
\hline Monitoring and controlling resources & -0.10 & 0.78 & 0.22 & 0.15 & -0.12 \\
\hline
\end{tabular}

Note: Boldface indicates assignment of the item to the scale shown

\section{References}

1. Steinmetz E. Americans with disabilities: 2002. Washington, DC: US Bureau of the Census; 2006. Report No P70-107.

2. US Census Bureau Table S1802. Selected economic characteristics for the civilian noninstitutionalized population by disability status. 2008. [Web-based tabulation] Available from http://www. census.gov/hhes/www/disability/2006acs.html cited 2008 October 4 .

3. Yelin EH, Trupin L. Disability and the characteristics of employment. Monthly Labor Rev. 2003;126(5):20-31.

4. Schur LA. Dead end jobs or a path to economic well being? The consequences of non-standard work among people with disabilities. Behav Sci Law. 2002;20(6):601-20. doi:10.1002/bs1.512.

5. Schur LA. Barriers or opportunities? The causes of contingent and part-time work among people with disabilities. Ind Relat. 2003;42(4):589-622. doi:10.1111/1468-232X.00308.

6. Schur L, Kruse D, Blasi J, Blanck PD. Is Disability disabling all workplaces? Workplace disparities and corporate culture. Ind Relat. 2009;48(3):381-410.
7. US Bureau of Labor Statistics. National Compensation Survey. Occupational Wages in the United States, June 2006. Washington, DC: US Department of Labor; 2007.

8. Baldwin ML, Johnson WA. A critical review of studies of discrimination against workers with disabilities. In: Rodgers WM III, editor. Handbook on the economics of discrimination. Northampton, MA: Edgar Elgar Publishing; 2006. p. 119-57.

9. US Census Bureau. American community survey operations plan: release 1. Washington, DC: US Census Bureau; 2003.

10. Raudenbush SW, Bryk AS, Cheong YF, Congdon R. HLM 6: Hierarchical Linear and Nonlinear Modeling. Lincolnwood, IL: Scientific Software International; 2004.

11. Rabe-Hesketh S, Skrondal A. Multilevel and longitudinal modeling using stata. College Station, TX: Stata Press; 2008. p. 248.

12. Taylor KE, Walter J. Occupation choices of adults with and without symptoms of dyslexia. Dyslexia. 2003;9(3):177-85. doi: $10.1002 /$ dys.239.

13. Kaye HS. Disability Watch, Volume 2: The status of people with disabilities in the United States. Oakland, CA: Disabliity Rights Advocates, Inc.; 2001. 
14. Dray-Spira R, Gueguen A, Lert F. Disease severity, self-reported experience of workplace discrimination and employment loss during the course of chronic HIV disease: differences according to gender and education. Occup Environ Med. 2008;65(2):112-9. doi:10.1136/oem.2007.034363.

15. Walker WC, Marwitz JH, Kreutzer JS, Hart T, Novack TA. Occupational categories and return to work after traumatic brain injury: a multicenter study. Arch Phys Med Rehabil. 2006;87(12): 1576-82. doi:10.1016/j.apmr.2006.08.335.

16. Laine S, Gimeno D, Virtanen M, Oksanen T, Vahtera J, Elovainio M, et al. Job strain as a predictor of disability pension: the Finnish Public Sector Study. J Epidemiol Community Health. 2009;63(1): 24-30. doi:10.1136/jech.2007.071407.
17. Rojewski JW. Occupational and educational aspirations and attainment of young adults with and without LD 2 years after high school completion. J Learn Disabil. 1999;32(6):533-52. doi: 10.1177/002221949903200606.

18. Pagan R. Is part-time work a good or bad opportunity for people with disabilities? A European analysis. Disabil Rehabil. 2007;29(24):1910-9. doi:10.1080/09638280701192881.

19. Stapleton DC, O'Day BL, Livermore GA, Imparato AJ. Dismantling the poverty trap: disability policy for the twenty-first century. Milbank Q. 2006;84(4):701-32. doi:10.1111/j.14680009.2006.00465.x.

20. Schartz HA, Hendricks DJ, Blanck P. Workplace accommodations: evidence based outcomes. Work. 2006;27(4):345-54. 